\title{
Research on Development Direction of College English Teaching and ESP
}

\author{
Liailun Chen $^{1, a}$ \\ ${ }^{1}$ Wuhan Technical College of Communications, Wuhan, Hubei Province, 430065 \\ aemail,
}

Keywords: Development Direction, College English Teaching, ESP

\begin{abstract}
As English proficiency continue to improve of high school graduates, as well as society's high-quality demand is increasing for compound talents to, college English teaching curriculum is facing the problems of development direction. The importance of ESP teaching in college English teaching has got more and more experts and scholars' agree. This paper describes the definition of ESP and its relationship with the general-purpose English. Finally, we promote the view that college English teaching should gradually bring focus to ESP teaching development.
\end{abstract}

\section{Introduction}

In the Department of Higher Education to develop "College English Curriculum Requirements" (draft), while the Ministry of Education Division of the foundation also developed and completed the first "high school English curriculum standards' development work. Comparing these two direct the University and high school English teaching English teaching "requirements" and "standard", had to make us think the direction of development of college English teaching.

"Standard" clearly defined high school English curriculum aims to "cultivate students 'comprehensive ability to use language"; and "demand" also proposed a "college English teaching goal is to develop students' English language proficiency, especially in listening and speaking ability." Senior English is divided into six, seven, eight, and nine four levels. Reach nine outstanding high school graduates English vocabulary will reach 4500, high school graduates are generally required to achieve eight of the 3300 vocabulary. According to the "College English Curriculum Requirements" (draft), the vast majority of college students learning English through a number of years, required to achieve the general requirements, vocabulary is only 4500 words. Other oral and written language proficiency requirements generally require only high school English eight and nine standards between.

The problem is not that "high school English curriculum standards" and made our current college English teaching almost the same goals and competency standards, but also the use of our current college English teaching the same curriculum and curriculum. "Standard" all English courses divided into required courses and electives. Required courses in English 1,2,3,4,5,6 comprehensive course; there are elective courses in English and Chinese translation, Practical Writing, Newspaper Reading, English speaking, secretarial English, scientific English, English literature appreciation, film appreciation courses. It can be said that it is now almost all the university courses in English are all transplanted the past.

This brings us to the College English Teachers natural to worry about this problem: With the vigorous development of primary and secondary English teaching, "high school English curriculum standards" actively promote, if after a few years, the majority of the country's high school graduates admitted to the University substantially achieved "High school English curriculum standards", namely the University foundation of English Teaching (general English) targets most or all of the high school realized (by now, "college English Curriculum requirements" general requirements to measure), then college English teaching should be how do? curriculum and the development direction of college English teaching what? college English teachers way out? this is not sensational, but in the near future must face a problem.

We believe that the time has come to actively prepare for teaching English for Specific Purposes 
time. Conditional universities, especially universities, should first try to make the center of gravity of college English teaching gradually shifted towards the direction of teaching English for Specific Purposes.

\section{The Definition of ESP}

ESP (English for Specific Purposes) refers to the ESP, which is a branch of the English teaching field. Hutchinson and Waters (1987) to the ESP under the following definition: ESP is an explore theoretical approaches based on language teaching needs of learners (ESP is an approach to language teaching in which all decisions as to content and method are based on the learner's reason for learning). Four absolute feature ESP include: 1) curriculum must meet the specific requirements of learners; 2) the contents of certain disciplines and career-related; 3) vocabulary and syntax with a particular focus on the discourse of professional or career-related the use of language; 4) and EGP (English for general Purposes, general English) have significant differences. From the above it can be seen four absolutely special, it said specific target ESP oriented English teaching is based on the needs of learners and analysis basis. ESP development experience: the language domain analysis (register analysis), text analysis (discourse analysis), the target scenario analysis (target situation analysis); skill analysis (skills and strategies analysis); learning-centered (a learning-centered approach) five stages.

\section{The Current Situation and Problems of ESP Teaching}

Teaching Mode. ESP teaching in China started college early and slower development. Due to historical reasons and knowledge structural problems of teachers, teaching our ESP emerged from the teaching of English teachers and teaching by the Professional Teachers in two modes. Most English teachers teach ESP due to limited expertise, often used to teach basic English teaching methods EPS to vocabulary and grammar-based teaching; and teach most courses ESP teachers due to lack of experience teaching language, just as the ESP class teaching expertise to translate the main.

Cultural Literacy. Both teaching modes overlooked an important factor in professional cross-cultural communication, namely teaching cultural factors. At the same time, due to the influence of traditional departmental system, our scientific and technical personnel at the time of writing product descriptions and other professional documents used to focusing on technical details and ignore the audience, do not pay attention for the communication objects of different cultural background of requirements analysis, write professional documents difficult meet the needs of users, there may even lead to misunderstandings and cause disputes, thereby affecting our export products in the international market competitiveness.

Communication Rhetoric. According to the analysis published in our country, "University of Economics and English", "Advanced Medical English" and 12 ESP materials, most textbooks still register analysis based curriculum, namely induction vocabulary and grammar language points appear in the text, compiled fill in the blank, select or translation exercises, students are able to grasp the correct usage of these words. Basic English vocabulary teaching stage is necessary, but in the English vocabulary teaching by teaching period still is not enough. Allen \& Widdowson believes that students (in the professional communication) faced major difficulties in the system is not a lack of knowledge of English, but are not familiar with English usage, namely, how to use the sentence to perform different communicative acts. Therefore, ESP textbook teaching content should be introduced rhetoric.

Application Skills. Our ESP textbooks writing training in the use of relatively simple product approach, which is given for students to imitate model essay, writing little to explain the method and does not involve writing and related skills. With the popularity of computer applications, professional document writing is no longer a simple process of writing, editing and design documents have become part of writing is an important means to improve the efficiency of information exchange. In recent years, full-time editorial staff typing and reduce the phenomenon of 
design documentation and editing has become a professional writing staff necessary for the application of skills. Although students can learn computer class application the various functions of the school, but rarely taught computer classes specifically how to use these features effectively design and editing English documents. This language teaching and application of skills from the phenomenon affecting improve students' English Proficiency.

\section{ESP and the Development Direction of College English Teaching}

Diversification Demand for Professionals. For this stage of society, any business requires a wide range of talents in the English language as well. While many students can speak very fluent English, but only one aspect, or business, or normal, at this stage of enterprise integration requirements. Therefore, in the direction of English teaching universities need to change, so as to develop a wide range of talents, thus contributing to the development of enterprises, promote the progress of the country. In the direction of development of college English teaching, EPS is the best choice, but be careful not to completely copy from the ESP is required according to each university's strengths and weaknesses, make the appropriate changes, so as to produce more students large positive impact and to foster a more diverse talent. This can give full play to the student's own advantage. At the university level, students of their own advantages and disadvantages have a more clear understanding, so this feature ESP can effectively help students to avoid weaknesses in the future development, I believe that you can add a larger boost. If a student is poor in terms of memory, you can choose a more rich curriculum to challenge yourself, to overcome this disadvantage; you can also choose a strong understanding of the course, play to their strengths, we can say, ESP can be tailored for each student course, to make them uniform curriculum to say "goodbye."

The Specialized Needs Are Strengthening. In today's rapid social development, talent is the greatest competitive edge. And competitive talent itself is that professional. Therefore, in order after graduation have a better development and we must have excellent professional knowledge. ESP in our country's development trends of college English teaching professional will be able to compensate for weak good this shortcoming. Many students are not enough for their excellent professional and distress and we assume that a university stage already adopted EPS. So students in learning English, they must be with certain companies or certain industries have a lot of contact, students can be directed according to their preferences, so that you can have a specific goal in learning when teachers can when teaching, more specialized teaching. Such students' professional will be very tough to go interview any business and there will be a good result. The industry will have a better development. Students determine their professional future, so the direction of English teaching in college, need to have a good grasp, not always comprehensive teaching so that students are aware of the many aspects, but not proficient in any aspect, Therefore, not firms.

ESP Will Become A Trend. From the students' English has improved continuously, our country's economic development and the needs of social perspective, Fudan University, Professor Cai Jigang has published articles in Foreign core journals, emphasizing the focus of college English teaching will gradually shift to English for Specific Purposes teaching direction, Teaching English for Specific purposes mainstream appeal should gradually become college English teaching. CAI group just that: college English teaching has never been like this cause such widespread attention and discussion. Professor Lu Siyuan emphasized: EPS as an application in English, it is in the past, now and in the future for China's economic construction and made outstanding contributions to cultural development, should enjoy the same status General English and Foreign Language Teaching in conjunction therewith constitute and mainstream research, because "it can satisfy all sectors of society and in all areas in the shortest possible period of foreign language talents growing demand." Thus, ESP in the future development, will be widely used, it will become the mainstream of the vast majority of college English teaching development orientation. In fact, from some of the existing situation, EPS has been a wide range of use, but not too greatly improved, but with the acceleration of social progress, more and more demands of the students, ESP will be applied more and more widely. In some of the developed cities and regions, EPS has been applied for a long time, and to wide acclaim. 
ESP Focus on Practical Results. After the study, we found that, EPS actually very pragmatic effect. After some well-known universities, use ESP, even if not get the desired results, it will not have adverse effects. The reason is that the conflict does not occur between the many features EPS, on the contrary, between the ESP feature is mutually supplementary, between each other can play a positive impact. For this stage of development, the development direction of college English teaching to be addressed, EPS generation is a hope, but also a breakthrough. More importantly, pay attention to the actual effect of the ESP is suitable for our specific case and there is a broad prospect for future development.

\section{Conclusion}

Although more and more experts and scholars have realized the urgency and importance to strengthen the ESP teaching of University, but in terms of theory and practice in terms of teaching, the current University of ESP teaching, there are still many problems to be further enhanced and perfect. Although China's ESP research thirty years of development has made considerable achievements, but we are still in the exploration process, the need to work together various departments, to improve the teaching level ESP, so as our socialist economic construction deliver more highly qualified personnel.

\section{Acknowledgements}

Fund Project: College Project of Wuhan Technical College of Communications: Research on Problems and Countermeasures of Vocational Public English Teachers' Professional Development (q2015006)

\section{References}

[1] Jia Xinzhang, Li Jingyuan. Foreign Language Teaching, Vol. 6 (2014) No 53, p.25-26

[2] Peng Sue, Wang Yunhui, Wang Qunyong. Chinese Education, Vol. 12 (2015) No 27, p.74-76

[3] Jing Jianfen. Foreign Language Teaching, Vol. 30 (2014) No 19, p.144-145

[4] Wang Kuailiang. Shanghai Polytechnic University, Vol. 29 (2008) No 27, p.21-23

[5] Zhang Gongxu, Sun Jing. Foreign Language Teaching, Vol. 8 (2013) No 27, p.57-60 